Research Article / Araştırma Makalesi

\title{
THE INVESTIGATION OF RELATIONSHIP BETWEEN CORRUPTION PERCEPTION INDEX AND GDP IN THE CASE OF THE BALKANS*
}

\author{
Asst. Prof. İbrahim Emre GÖKTÜRK** (D) \\ Necmettin Erbakan University, FHS, Konya Turkey, (iegokturk@gmail.com) \\ Asst. Prof. Hüseyin Serdar YALÇINKAYA (D) \\ Necmettin Erbakan University, Konya Ereğli Kemal Akman VS, Konya, Turkey, (syalcinkaya@erbakan.edu.tr)
}

\begin{abstract}
One of the issues considered important by investors is the concept of security. Investors want to continue their commercial activities in areas, where protection of rights, risks can be predicted, and profitability is high. It is thought that in the regions, where these elements were determined, commercial activities widen and they positively affect GDP of the invested country. Depending on this forecast, the relationship between the annual data of Corruption Perception Index, prepared by Transparency International, and the GDP data of the Balkan countries will be investigated.In this Study, panel causality analysis of Balkan countries will be made by using the annual GDP, foreign direct investments, and Corruption Perception Index data for 2008-2016 and the results obtained will be discussed.
\end{abstract}

Keywords: Balkan States, Corruption Perception Index, GDP.

\section{BALKANLAR ÖZELINDE YOLSUZLUK ALGI ENDEKSI VE GSMYIH ARASINDAKI İLIŞKININ İNCELEMESI}

\begin{abstract}
ÖZET
Yatırımcılar tarafından önemli görülen konuların başında güvenlik kavramı gelmektedir. Yatırımcılar ticari faaliyetlerini, hakların savunulduğu, risklerin öngörülebildiği ve karlılı̆̆ın yüksek olduğu bölgelerde sürdürmek isteyeceklerdir. Belirtilen bu unsurların bir araya geldiği bölgelerde ticari faaliyetler genişleyerek, yatırım yapılan ülkenin GSYIH'sine olumlu yönde etki edeceği düşünülmektedir. Bu öngörïye bağlı olarak Uluslararası Şeffaflık Örgütï tarafindan yıllık olarak hazırlanan Yolsuzluk Algı Endeksi'nin verileri ile Balkan ülkelerinin GSYİH verileri arasında ilişsinin varlığı araştırılacaktır. Araştırmada Balkan ülkelerinin 2008-2016 arası yıllık GSYIH doğrudan yabancı yatırımlar ve Yolsuzluk Algı Endeksi verileri üzerinden panel nedensellik analizi gerçekleştirilecek ve elde edilen sonuçlar tartışılacaktır.
\end{abstract}

Anahtar Kelimeler: Balkan Ülkeleri, Yolsuzluk Algı Endeksi, GSYIH.

\footnotetext{
An earlier version of this paper was presented as a verbal statement at the 4th Sarajevo International Conference on Social Sciences, Sarajevo, April 2018

** Corresponding author
} 


\section{Introduction}

The shortest and clearest definition of corruption is the definition made World Bank. According to this definition, corruption is the abuse and exploitation of public authorization for private benefits (Nguyen, et al., 2017). What is wanted to be expressed with saying of private benefit is that individual forms an interest for his/her own benefit and maakes action in this direction (Ackerman, 1999: 2). Corruption can form through that several groups coming together with the same aims sometimes make actions in the direction of interest not only individually (Vito, 1998: 2). It shows that the concept of corrupttion is so important with social priority that is not protercted and with movements of individual or groups forming dominance and interest against others for the sake of arranging social process.

Bribery and debit as well as seizure, fraud, favoritism, being stolen of every sorts of government property, engrossing, and manipulation, synonymously referred to corruption, can be considered corruption (Andving, et al., 2000). The social equivalent or reaction of these terms depends on providing social order and becoming established of social culture. In the countries whose socail status is high, while the individuals hesitate in the face of this reaction, in the countries, where social order cannot be provided, as a result of that individual does not adequately face to social reaction, this illegal values that increase impede and retard social togetherness to strengthem. Moreiver, the increase of corruption and similar actions brings together a collapse in moral and cultural meaning.

Although public area mostly comes into mind when mentioned about corruption, nretrogression and degeneration that will occur of making decisions of private agencies as well as public institutes should be also expressed as corruption. In private sector, especially bidding and recruiting processes, corruption actions are seen (Gillanders \& Neselevska, 2018)

Corruption is also a social and economic problem. In socialization process, it comes into our face as a problem impeding individuals to fairly and equally live and bringing to a standstill the function of the cultural, political, and economic elements of the society. Corruption, utilising compettive power, reduces and destruct economic and social development as a result of struggle individuals make for their own favoors to obtain more rent rather than utilizing . (Stapenhurst, 2000: 9-10)

Historical and cultural values of the countries and their relationships with the close and away other countries regionally that are effective in the formation of these relationships will determine the attitude of society against corruption. The region used in the study is Balkan countries, which have the historical and cultural pasts, carry similarities from the cultural, moral, and traditional point, which have economic qualities to each other, and the relationship of corruption with economic magnitudes specific to Balkan states was tried to be examined.

\section{Corruption Perception Index}

The literature review made show us that corruption forms contradiction with the concepts such as economic growth, GDP, and development and harms to the general economic policies. All over the world, in the studies and discussions on impeding corruption, many new programs and strategic targets are presented. International acceptable political entities such as Organization of Economic Cooperation and Development (OECD), United Nations (UN)and 
European Union (UN) develop conventions and principles to provide improvement -aimed reform as prioritized targets in this area about struggle with corruption and targets on forming a corruption -preventive culture through creating international public opinion, reducing corruption, and becoming widespread good governance.

One of the organizations working for reducing to reduce coruption to inimum leverl and worlwide appreaciared due to its corruption preventive studies is also Transparency International. This organization considers corruption as the most important problems of comtemporary world and suggests that corruption negatively affects the economic development of the society; that it impedes the effective use of public resources and public policies; that it harms to the development of private sector: and that it has negative effects on the people, who struggle to survive economically (Lučić et al., 2016).

Making corruption-free of all sectors of the society will be possible through a transparent, fair, and accountable state structure. Transparency International, established in actionn plan of making free the undesirable effects of corruption on the society and acting with the wide mass, in order to achieve this target, accounts for Corruption Perception Index every year and, subjecting it to country basis, examines the relationship of countries to corruption (Ulman, 2014: 440)

This index, the dimension of relationship of countries with corruption, shows that how transparent and how democratic management they exhibit. This case is important in terms of that countries show the quality of livable countries intern to all over the world. Also when also looked at economic point of view, this index, an indicator of democratic and transparent management, increasing the trustworthiness of the country, raises its credibility and is used as a credit standard that also increases the power to be able to attract foreign capital. That the countries whose index score is good is the leading countries in international trade is the most important indicator of this.

The index, first started in 1995, attracted interest in international arena and was accepted in the short time. The organization, whose original target is to prevent corruption via transparency and accountability and reassurance, was appreciated from this point of view (www.transperency.org./cpi). In the new age, it is known that without having these values, global policies suggested for global crises will be under risk.

When looked at all over the world, there is a serious corruption problem in $68 \%$ of the countries (www.transperency.org./cpi). For being able to implement strategic aims against corruption and make reforms, first of all, it is necessary to identify corruption in the real meaning. But it is not easy to clearly identify and measure corruption. Then, in this case, how does Corruption Perception Index work and what is made it trustable?

While Transparency International forms this index, the evaluations made by the independent and credible institutes and view survey are utilized. These surveys and evaluations include the questions related to giving a bribe to public officials, withdrawals from public biddings, charging public funds to debit, and effectiveness of efforts to struggle with corruption (Rose \& Mishler, 2010). Since corruption is a secret activity that is largely difficult to measure, the perceptions are used to come over this difficulty. The data obtained since the first years when index has been formed have proved that perceptions are reliable corruption prediction. 


\section{The Case of Balkan Countries According to Corruption Perception Index}

Balkans meaning steep and forestry range of mountains in lexical meaning take place in southeast part of the continent Europe and the west and northwest of Anatolia (Vasileva, 2017: 34). Before collapsing of East Bloc, Balkan states consisted of Albania, Bulgaria, Romania, Turkey, Greece, and Yugoslavia. Together with collapse of East Bloc, Yugoslavia diintegrated and Bosna- Herzegovna, Serbia, Chrotia, Kosovo, Macedonia, Montenegro, and Slovenia were included in Balkan states. At the present day, there are 12 states qualified as Balkan States.

Our study studies, according to the data of transparency index of Balkan countries, whether or not there is a relationship between foreign direct investment and GDP. From this point of view, in the following table, the ranks of Balkan countries in the world according to Corruption Perception Index between the years of 2008-2018 are given.

Table 1: The Ranks of Balkan Countries in the World According to Corruption Perception Index Between the Years of 2008-2018

\begin{tabular}{lccccccccccc}
\hline & $\mathbf{0 8}$ & $\mathbf{0 9}$ & $\mathbf{1 0}$ & $\mathbf{1 1}$ & $\mathbf{1 2}$ & $\mathbf{1 3}$ & $\mathbf{1 4}$ & $\mathbf{1 5}$ & $\mathbf{1 6}$ & $\mathbf{1 7}$ & $\mathbf{1 8}$ \\
\hline Albania & 85 & 95 & 87 & 95 & 113 & 116 & 110 & 88 & 83 & 91 & 99 \\
\hline Bosnia-Herzegovina & 92 & 99 & 91 & 91 & 72 & 72 & 80 & 76 & 83 & 91 & 89 \\
\hline Bulgaria & 72 & 71 & 73 & 86 & 75 & 77 & 69 & 69 & 75 & 71 & 77 \\
\hline Croatia & 62 & 66 & 62 & 66 & 62 & 57 & 61 & 50 & 55 & 57 & 60 \\
\hline Greece & 58 & 71 & 78 & 80 & 94 & 80 & 69 & 58 & 69 & 59 & 67 \\
\hline Kosovo & - & - & 110 & 112 & 105 & 111 & 110 & 102 & 95 & 85 & 93 \\
\hline Macedonia & 72 & 71 & 62 & 69 & 69 & 67 & 64 & 66 & 90 & 107 & 93 \\
\hline Romania & 70 & 71 & 69 & 75 & 66 & 69 & 69 & 58 & 57 & 59 & 61 \\
\hline Slovenia & 26 & 27 & 27 & 35 & 37 & 43 & 40 & 34 & 31 & 34 & 36 \\
\hline Serbia & 85 & 83 & 78 & 86 & 80 & 72 & 78 & 71 & 72 & 77 & 87 \\
\hline Turkey & 58 & 61 & 56 & 61 & 54 & 53 & 64 & 66 & 75 & 81 & 78 \\
\hline A total numb. of countries & 180 & 180 & 178 & 183 & 176 & 177 & 175 & 168 & 176 & 180 & 180 \\
\hline
\end{tabular}

Source: www.transparency.org/cpi former information

The results of Corruption Perception Index, prepared in the light of information given by at least 3 international institutes was formed by measuring the perceptions of the specialists, non-governmental organizations, and representatives of business world regarding the corruption in public sector.

In the table, ranking of 12 Balkan countries according to the years and the number of country participating in Corruption Perception are given. Among Balkan countries, Slovenia, the country whose corruption perception index is the lowest, is in the $36^{\text {th }}$ position. The countries, in which this index is the highest, are Kosovo and Albania. When generally regarded to, according to Corruption Perception Index, world ranking range approximately the same. 
The state of Balkan countries that are present in middle ranks in corruption perception was evaluated by using the data of 2016, when the most healthy data were drawn for every country and the following table was formed.

Table 2: Balkan Countries (Population, GDP and DFI)

\begin{tabular}{lccccccccc}
\hline & Population* & $\mathbf{\%}$ & $\mathbf{N}$ & $\mathbf{G D P} * *$ & $\mathbf{\%}$ & $\mathbf{N}$ & DFI*** & $\boldsymbol{\%}$ & $\mathbf{N}$ \\
\hline Romania & $19,699,312$ & $\mathbf{1 3 . 9}$ & 2 & $187,592,037,839.97$ & $\mathbf{1 2 . 6 6}$ & 3 & $5,372,961,305.3$ & $\mathbf{1 7 . 3 8}$ & 2 \\
\hline Greece & $10,770,521$ & $\mathbf{7 . 6 1}$ & 3 & $192,690,813,126.86$ & $\mathbf{1 3 . 0 1}$ & 2 & $3,060,785,236.6$ & $\mathbf{9 . 9 0}$ & 3 \\
\hline Bulgaria & $7,127,822$ & $\mathbf{5 . 0 3}$ & 4 & $53,237,882,472.71$ & $\mathbf{3 . 5 9}$ & 4 & $1,179,040,000$ & $\mathbf{3 . 8 1}$ & 7 \\
\hline Croatia & $4,174,349$ & $\mathbf{2 . 9 5}$ & 6 & $50,714,957,390.54$ & $\mathbf{3 . 4 2}$ & 5 & $1,864,321,647.9$ & $\mathbf{6 . 0 3}$ & 5 \\
\hline Slovenia & $2,065,042$ & $\mathbf{1 . 4 6}$ & 10 & $44,708,598,648.86$ & $\mathbf{3 . 0 2}$ & 6 & $1,461,635,215.7$ & $\mathbf{4 . 7 3}$ & 6 \\
\hline Serbia & $7,058,322$ & $\mathbf{4 . 9 8}$ & 5 & $38,299,854,688.13$ & $\mathbf{2 . 5 8}$ & 7 & $2,300,135,289.1$ & $\mathbf{7 . 4 4}$ & 4 \\
\hline Bosnia & $3,516,816$ & $\mathbf{2 . 4 8}$ & 7 & $16,910,277,133.65$ & $\mathbf{1 . 1 4}$ & 8 & $272,521,285.27$ & $\mathbf{0 . 8 8}$ & 10 \\
-\&Herzeg. & & & & & & & & & \\
\hline Albania & $2,876,101$ & $\mathbf{2 . 0 3}$ & 8 & $11,863,865,978.09$ & $\mathbf{0 . 8 0}$ & 9 & $1,044,184,334.8$ & $\mathbf{3 . 3 8}$ & 8 \\
\hline Macedonia & $2,081,206$ & $\mathbf{1 . 4 7}$ & 9 & $10,899,583,154.65$ & $\mathbf{0 . 7 4}$ & 10 & $549,371,101.55$ & $\mathbf{1 . 7 8}$ & 9 \\
\hline Kosovo & $1,816,200$ & $\mathbf{1 . 2 8}$ & 11 & $6,649,888,888.89$ & $\mathbf{0 . 4 5}$ & 11 & $239,338,811.22$ & $\mathbf{0 . 7 7}$ & 11 \\
\hline Turkey & $79,814,871$ & $\mathbf{5 6 . 4}$ & 1 & $863,721,731,068$ & $\mathbf{5 8 . 2 9}$ & 1 & $13,343,000,000$ & $\mathbf{4 3 . 1 6}$ & 1 \\
\hline Total & $141,622,865$ & $\mathbf{1 0 0}$ & $1,481,663,617,603$ & $\mathbf{1 0 0}$ & $30,913,960,820$ & $\mathbf{1 0 0}$ & \\
\hline
\end{tabular}

*Population, total 2016, **GDP (current US\$)2016, ***Foreign direct investment, inflows (BoP, current US\$) 2016 Source: https://data.worldbank.org/country/

Among Balkan Countries, the country, which has a remarkable advantage in terms of population, GDP, and foreign direct investment, is Turkey. In the same values, the country that has the lowest values is Kosovo. But in order to make better analysis, the ranking of Balkan countries were formed in the table. When looked at this ranking, the effective country in terms of GDP direct foreign investment according to its population is Slovenia. Although Slovenia is the last rank in terms of population, in terms of GDP and foreign direct investment is in the $4^{\text {th }}$ order. Again, while Serbia and Croatia also are seen to be in the better rank in terms of foreign direct investment according to their populations, when evaluated in terms of GDP and foreign direct investment according to the population, the countries that are in the worst position are Bosnia- Herzegovina and Bulgaria. When regarded to the averages of Bulgaria and Bosnia Herzegovina in terms of Population, it is seen that the rankings in Balkan Countries attracting foreign direct investments are in more behind.

\section{Literature Review Related to Corruption Perception Index and Macroeconomic Magnitude}

The presence of the studies carried out related to perception index and macro variables show that corruption perception index is an academically important indicator. In the literature studies carried out, generally, it comes to our face that the variables such as GDP, income distribution, employment, foreign direct investments, national income, and welfare level are used. 
In the study carried out by Damania et.al, the relationship between income and corruption was tried to be identified. According to Damania et al., per capita national income forming in a society increases, as corruption decreases. In other words, there is a negative directional relationship between income and corruption (Mani et al., 2004)

In the study carried out by Ugur and Dasguptan, the effects of corruption perception index on economic growth in lower and higher income countries were studied. According to the findings they obtained, corruption negatively affects economic growth in both country group. The indirect effects of corruption on economic growth (the effects forming human capital and public finance) are higher its direct effects. In addition, in the lower income groups, the effect of the decrease in corruption on economic growth becomes more effective compared to high income groups (Uğur \& Dasgupta, 2011)

Another variable associated with corruption is income distribution. According to Paldam, one of economic variables affecting corruption in the countries is income distribution. In the countries, in which there is skewed income distribution, illegal earning becomes attractive (Paldam, 2002: 8) Paldam (2002), in the countries, where Gini coefficient is high, depending on income injustice, claims that corruption will also rise. In order to support this saying of him, in the case, in which the value that will be obtained by Gini coefficient show income injustice, using Gini coefficient, disorder that will realize in income will significantly increase corruption (Paldam, 2002)

Paldam (2001), in anotjer study, he identified that corruption perception was high and that corruptiom perception decreased as countries enriched. In addition, as inflatin increase, corruption level increases. Paldam, in the same study, corruption level increases, as inflation increases. Paldam, in the same study, except economic variables, identiified that the religion and moral values had effects on corruption (Paldam, 2001)

Gurgur \& Shah (2014), in the study they carried out, studied the relationship between management style and corruption. It was identified that in a decentralized management system, corruption decreases and, increase in unitary system. Gurgur and Shah point out that increase of welfare level in a country will decrease corruption (Gurgur \& Shah, 2014)

Nazar Mustapha (2014), in the study he carried out, studied the relationship between corruption and national income per capita. In the direction of the data between 2003 and 2011, Mustapha that makes panel data analysis identified that there was significantly negative on per capita income (Mustapha, 2014)

Also in a study Thach et al (2017) carried out, corruption and economic growth were compared In a study by using the data of 19 Asian countries covering the period of 2004-2015, the effect of corruption on economic was analyzed. The study results show that corruption forms an impediment on economic growth of Asian countries. Together with corruption, it was found that institutional quality, developedness of democracy, and economic freedom played important role in economic growth (Thach et al., 2017)

In the studies Rothstein and Holberg (2011) with the data belonging to World Bank and obtained from the various countries of the world, it is shown that as corruption levels of countries increase, their GDP, economic growth, and individual incomes decrease (Sören \& Rothstein, 2011) 
In the studies, carried out by Tazi and Daoodinin, individual leading to corruption will result in the increase of public investments. But this increase will not increase effectiveness. The reason for this is that investments are high-cost. Also, public output is of poor quality good and service (Tanzi \& Davoodi, 2000)

\section{Methodology and Dataset}

In the study carried out, the effects of the transparency levels Balkan countries have on their economic growth and the levels of foreign direct investment realized from the other countries to these countries were studied. Since the universe of the study is Balkan Countries, transparency indices of the countries shown in Table 3, GDP, and sums of foreign direct investments, and the data between 2000-2017 were used. Of course, although in the region specified there are 12 countries, due to the fact that the data of Montenegro belonging to the past years are not present, panel data analyses were made on 11 countries.

Table 3: Transparency Index Values of Balkan Countries

\begin{tabular}{lcccccccc}
\hline & $\mathbf{2 0 1 0}$ & $\mathbf{2 0 1 1}$ & $\mathbf{2 0 1 2}$ & $\mathbf{2 0 1 3}$ & $\mathbf{2 0 1 4}$ & $\mathbf{2 0 1 5}$ & $\mathbf{2 0 1 6}$ & $\mathbf{2 0 1 7}$ \\
\hline Albania & 33 & 31 & 33 & 31 & 33 & 36 & 39 & 38 \\
\hline Bosnia - Herzegovina & 32 & 32 & 42 & 42 & 39 & 38 & 39 & 38 \\
\hline Bulgaria & 36 & 33 & 41 & 41 & 43 & 41 & 41 & 43 \\
\hline Croatia & 41 & 40 & 46 & 48 & 48 & 51 & 49 & 49 \\
\hline Greece & 35 & 34 & 36 & 40 & 43 & 46 & 44 & 48 \\
\hline Kosovo & 28 & 29 & 34 & 33 & 33 & 33 & 36 & 39 \\
\hline Macedonia & 41 & 39 & 43 & 44 & 45 & 42 & 37 & 35 \\
\hline Romania & 37 & 36 & 44 & 43 & 43 & 46 & 48 & 48 \\
\hline Slovenia & 64 & 59 & 61 & 57 & 58 & 60 & 61 & 61 \\
\hline Serbia & 35 & 33 & 39 & 42 & 41 & 40 & 42 & 41 \\
\hline Turkey & 44 & 42 & 49 & 50 & 45 & 40 & 41 & 40 \\
\hline Balkan Average & 38.73 & 37.09 & 42.55 & 42.82 & 42.82 & 43.00 & 43.36 & 43.64 \\
\hline
\end{tabular}

As seen in Table 3 average transparency values of Balkan Countries stays below 50 in all study periods and, according to this, it reveals that Balkans region develop themselves. However, in return to this negative situation, it is a case that has to be stated that the average values of Balkan Countries show a continuous improvement toward the last periods. It is understood that the country becoming in the best positions in terms of transparency values is Slovenia, and the countries having the lowest value are Macedonia and Kosova 
The examination of Balkan Countries in terms of their economic sizes was made in Table 4, and in the direction of these data, it is understood that the largest economic structure of the country is Turkey and this is followed by Greece, while the weakest countries from economic point of view are Kosovo, Macedonia, and Albania.

Table 4: Economic Sizes of Balkan Countries

\begin{tabular}{lcccccccc}
\hline $\mathbf{x}$ Million \$ & $\mathbf{2 0 1 0}$ & $\mathbf{2 0 1 1}$ & $\mathbf{2 0 1 2}$ & $\mathbf{2 0 1 3}$ & $\mathbf{2 0 1 4}$ & $\mathbf{2 0 1 5}$ & $\mathbf{2 0 1 6}$ & $\mathbf{2 0 1 7}$ \\
\hline Albania & 11927 & 12890.9 & 12319.8 & 12776.3 & 13228.2 & 11335.3 & 11863.9 & 13039.35 \\
\hline Bulgaria & 50610 & 57418.4 & 53903 & 55758.7 & 56732 & 50199.1 & 53237.9 & 56831.52 \\
\hline $\begin{array}{l}\text { Bosnia - } \\
\text { Herzegovina }\end{array}$ & 17176.8 & 18644.7 & 17226.8 & 18178.5 & 18558.3 & 16209.7 & 16910.3 & 18168.58 \\
\hline Greece & 299361.6 & 287797.8 & 245670.7 & 239862 & 237029.6 & 195541.8 & 192690.8 & 200288.20 \\
\hline Croatia & 59665.4 & 62236.8 & 56485.3 & 57769.9 & 57080.4 & 48921.9 & 50715 & 54849.18 \\
\hline Serbia & 39460.4 & 46466.7 & 40742.3 & 45519.7 & 44210.8 & 37160.3 & 38299.9 & 41431.65 \\
\hline Slovenia & 48013.6 & 51290.8 & 46352.8 & 48116.3 & 49904.9 & 43072.4 & 44708.6 & 48769.66 \\
\hline Turkey & 771876.8 & 832546.3 & 873981.8 & 950595.3 & 934167.8 & 859794.2 & 863711.7 & 851102.40 \\
\hline Kosovo & 5829.9 & 66649.3 & 6473.7 & 7072.1 & 7386.9 & 6440.5 & 6649.9 & 7128.69 \\
\hline Macedonia, FYR & 9407.2 & 10494.6 & 9745.3 & 10817.7 & 11362.3 & 10051.7 & 10899.6 & 11337.83 \\
\hline Romania & 167998.1 & 185362.9 & 171664.6 & 191549 & 199493.5 & 177911.1 & 187592 & 211803.3 \\
\hline
\end{tabular}

As also stated in introduction section, foreign direct investments are considerably important for the countries, which have insufficient capital. In this context, the countries, in order to be able to accelerate their economic developments and solve the unemployment problem, make many attempts. Balkan countries are not exception of this state. However, when we generally regard to all Balkan counties, it can be said that they remain incapable about attracting foreign capital. As seen in Table 4 , in the countries included in the study, the country that was able to succeed in the most foreign capital is Turkey, while those being unsuccessful are Kosovo, Macedonia, and Bosnia - Herzegovina.

Table 5: Foreign Direct Investments

\begin{tabular}{lcccccccc}
\hline $\mathbf{x}$ Million \$ & $\mathbf{2 0 1 0}$ & $\mathbf{2 0 1 1}$ & $\mathbf{2 0 1 2}$ & $\mathbf{2 0 1 3}$ & $\mathbf{2 0 1 4}$ & $\mathbf{2 0 1 5}$ & $\mathbf{2 0 1 6}$ & $\mathbf{2 0 1 7}$ \\
\hline Albania & 1090.11 & 1048.09 & 918.31 & 1254.27 & 1149.54 & 989.28 & 1044.19 & 1022.13 \\
\hline $\begin{array}{l}\text { Bosnia - } \\
\text { Herzegovina }\end{array}$ & 443.84 & 471.61 & 391.98 & 313.30 & 544.87 & 383.09 & 282.75 & 462.73 \\
\hline Bulgaria & 1842.90 & 2103.81 & 1788.11 & 1989.04 & 2067.54 & 2706.69 & 1655.55 & 1656.24 \\
\hline Croatia & 1424.11 & 1417.60 & 1465.10 & 937.31 & 3959.86 & 158.97 & 1864.32 & 2040.46 \\
\hline $\begin{array}{l}\text { Greece } \\
533.69\end{array}$ & 1092.09 & 1663.33 & 2945.42 & 2696.80 & 1268.31 & 3060.79 & 4021.76 \\
\hline $\begin{array}{l}\text { Macedonia, } \\
\text { FYR }\end{array}$ & 301.44 & 507.92 & 337.91 & 402.46 & 60.88 & 296.60 & 549.37 & 430.70 \\
\hline
\end{tabular}


Table 5 continued

\begin{tabular}{lcccccccc}
\hline Serbia & 1693.33 & 4929.90 & 1276.10 & 2059.70 & 1999.52 & 2345.15 & 2354.73 & 2878.82 \\
\hline Slovenia & 319.05 & 875.54 & 33.55 & 103.98 & 1019.29 & 1729.44 & 1446.04 & 1081.88 \\
\hline Kosovo & 490.16 & 534.97 & 293.20 & 371.51 & 199.79 & 343.26 & 243.73 & 324.80 \\
\hline Turkey & 9099.00 & 16182.00 & 13744.00 & 13563.00 & 13119.00 & 18002.00 & 13343.00 & 10889.00 \\
\hline Romania & 3213.74 & 2370.10 & 3047.57 & 3854.82 & 3869.20 & 4317.73 & 6252.04 & 4949.69 \\
\hline
\end{tabular}

\subsection{Methodology}

As stated in the previous sections, in Balkan Countries-specific, the effect of Transparency Index (CPI) on economic size (GDP) and foreign direct investments (FDI) is the main aim of our given study. Depending on the aim of the study, the necessary panel data were formed and, for not facing the problem with unit root, natural logarithms of the data were taken. The definitive statistics of panel series is as shown in Table 6 when the definitive statistics of panel data series are examined, according to the data of Jarque-Bera, while GDP remains below 3 , it is above InCP1 and InCP3 value and, according to this assessment, it is understood that $\operatorname{lnCPI}$ and $\operatorname{lnFDI}$ series do not exhibit normal distribution, while, lnGDP series exhibits normal distribution.

\section{Table 6: Definitive Statistics}

\begin{tabular}{lccc}
\hline & LnCPI & LnGDP & LnFDI \\
\hline Mean & 0.035955 & -0.003733 & 0.018611 \\
\hline Median & 0.038707 & 0.017304 & 0.000000 \\
\hline Maximum & 2.461945 & 0.180133 & 0.271934 \\
\hline Minimum & -3.261866 & -0.192411 & -0.126752 \\
\hline Std. Dev. & 0.908968 & 0.086135 & 0.076281 \\
\hline Skewness & -0.749993 & -0.276177 & 0.827891 \\
\hline Kurtosis & 6.777221 & 2.351944 & 4.000528 \\
\hline Jarque-Bera & 52.99319 & 2.326273 & 12.00774 \\
\hline Probability & 0.000000 & 0.312504 & 0.002469 \\
\hline Sum & 2.768561 & -0.287438 & 1.433032 \\
\hline Sum Sq. Dev. & 62.79288 & 0.563856 & 0.442225 \\
\hline Observations & 77 & 77 & 77 \\
\hline
\end{tabular}

In order to investigate the entity of unit root on the panel data formed, PP (Philips \& Peron) and ADF (Adjusted Ducker \& Fuller) unit root tests were made. For the sake of not going away from the aim of the study, reporting, in detail, of these tests whose econometric explanation is made in many article, will not be given place. The results of unit root tests were 
introduced in Table 7 As will be understood from unit root results, at the level of panel data formed, there is no problem with unit root. In addition, it is predicted that the homogeneity of the data set will directly affect the test types to be selected, and the data for which the Homogeneity Delta test was applied on the data set is shown in Table 7. As a result of this test, it is accepted that the data set is not homogeneous.

\begin{tabular}{lcc}
\hline Tests & Statistics & Prob. \\
\hline Delta T. & 168.524 & 0.0000 \\
\hline Delta $\mathrm{T}_{\text {adj }}$ & 170.282 & 0.0000 \\
\hline
\end{tabular}

Depending on these results obtained, the presence of possible relationship through panel data of transparency index, GDP, and panel data of foreign direct investment of Balkan countries will be tested by FMOLS, panel co-integration test, if there is a relationship, the direction of this relationship will be tried to be determined by Granger Causality Test.

Table 7: In CPI, In GDP, Ln FDI

\begin{tabular}{lcccccc}
\hline \multicolumn{1}{l}{ In CPI } & In GDP & Ln FDI & & & \\
\hline Method & $\begin{array}{c}\text { Statistic } \\
\text { Values }\end{array}$ & Probability & $\begin{array}{c}\text { Statistic } \\
\text { Values }\end{array}$ & Probability & $\begin{array}{c}\text { Statistic } \\
\text { Values }\end{array}$ & Probability \\
\hline PP-Fisher Chi-square & 558.539 & 0.0001 & 558.539 & 0.0001 & 136.787 & 0.0000 \\
\hline PP-Choi Z-stat & -432.664 & 0.0000 & -432.664 & 0.0000 & -7.594 & 0.0000 \\
\hline ADF-Fisher Chi-square & 505.766 & 0.0005 & 505.766 & 0.0005 & 67.623 & 0.0000 \\
\hline ADF-Choi Z-stat & -283.829 & 0.0023 & -283.829 & 0.0023 & -5.746 & 0.0000 \\
\hline
\end{tabular}

\subsubsection{FMOLS Test}

Predictors of panel Least Squares (LS), Dynamic Least Squares (DOLS), and Full Modified Least Squares (FMOLS), developed by Kao \& Chiang (1998); panel DOLS predictor and predictors, developed by Mark \& Sul (2003) are commonly used methods in the literature. The FMOLS method corrects the deviations in standard fixed effect estimators (caused by problems such as autocorrelation and variance). The DOLS method, on the other hand, is a method that can eliminate the deviations in static regression (especially caused by endogeneity problems) by including dynamic elements in the model (Kök et al., 2010: 8). The FMOLS method developed by Pedroni allows considerable heterogeneity between individual sections, taking into account the existence of possible correlation between the constant term, the error term and the differences of the independent variables. Pedroni (2000), also investigated the power of FMOLS method in small samples and calculated that the performance of $t$ statistics in small samples is compatible with Monte Carlo simulations "(Kök and Şimşek, 2006: 7-8; Gülmez, 2015: 24).

In this study, the panel FMOLS estimation methods developed by Pedroni $(2000 ; 2001)$ were considered, considering the inhomogeneity of the data set and other advantages. Panel 
FMOLS Pedroni (2000) panel FMOLS method developed by Pedroni $(2000 ; 2001)$ is based on the following panel regression model:

$$
\begin{aligned}
& \text { yit }=\alpha i t+\delta i t+\beta x i t+\mu i t \\
& \text { xit }=\text { xit-1 }+ \text { eit }
\end{aligned}
$$

In these equations, under the assumption that there is no dependence between cross sections forming the panel, yit represents dependent variable, xit, independent variable. In Equation (1), error terms is a stationary process and, if yit first degree integrated, there is long term co-integration relationship between yit and xit. $\beta$ 's indicates that long term co-integration vector (coefficient) that is necessary for prediction (Nazlığlu, 2010; Koçak \& Nisfet, 2018).

According to panel co-integration test, whose results are given in the Table 8 , since the null hypothesis of Balkan countries that there is no CPI and GDP is $\mathrm{P}=0.000$ an $\mathrm{P}<0.05$, it must be rejected. According to this implication, it is accepted that the alternative hypothesis that there is a panel co-integration between CPI and GDP

Table 8: Panel Co-Integration Test between GDP and CPI (FMOLS)

\begin{tabular}{lcccc}
\hline & Coefficient & Std. Deviation & t-Statistics & Probability \\
\hline LNCPI & 0.344100 & 0.071628 & 4.803 & 0.0000 \\
\hline R-squared & 0.186822 & There is Mean dependent & -0.002621 & \\
\hline Adjusted R-squared & 0.021174 & There is S.D. dependent & 0.088560 & \\
\hline S.E. of regression & 0.087617 & Sum squared resid & 0.414545 & \\
\hline Long-run variance & 0.001470 & & & \\
\hline
\end{tabular}

When the coefficients of co-integration emerging between CPI and GDP of Balkan countries are examined, in return to the $1 \%$ increase of CPI of Balkan Countries, it is estimated that $0.34 \%$ of increase will be experienced in GDP. This value identified is quite large and important quantity in terms of economic growth.

The presence of co-integration relationship between CPI and FDI in Balkan countries was examined in a distinct model from the model formed and its results were introduced in Table 9 according to co-integration test of the model formed, rejecting that the null hypothesis that there is no co-integration between CPI and FDI, it was accepted that there was a cointegration between the variables specified.

Table 9: $P$ anel Co-Integration Test between FDI and CPI (FMOLS)

\begin{tabular}{lcccc}
\hline & Coefficient & Std. Deviation & t-statistics & Probability \\
\hline LNCPI & 4.604654 & 1.591860 & 2.892626 & 0.0068 \\
\hline R-squared & 0.184304 & There is Mean dependent & 0.054651 \\
\hline Adjusted R-squared & -0.656882 & There is S.D. dependent & 0.904304 \\
\hline S.E. of regression & 1.164020 & Sum squared resid & 43.35815 \\
\hline Long-run variance & 0.153210 & & \\
\hline
\end{tabular}


In Balkan countries -specific, after identification of co-integration between FDI and CPI, when the effect of CPI on FDI through the co-efficient formed is interpreted, in return to the $1 \%$ increase of CPI, it is estimated that there will be an increase in FDI at the rate of 4.60. In the light of this information obtained, it is easily accepted that CPI will have positive and relatively large on both GDP and FDI. However, although positive relationship was identified between the variables, it will not be possible to say that which variable affects to each other without Granger Causality Analysis. In order to examine causality structures of the variables that are subject of analysis, using Panel Granger Causality Analysis was approved, and analysis results were given in Table 10 .

\section{Table 10: The Results of Panel Granger Causality Analysis}

\begin{tabular}{lcc}
\hline Null Hypothesis: & F-Statistic & Prob. \\
\hline lnGDP does not Granger Cause lnCPI & 0.06640 & 0.7975 \\
\hline lnCPI does not Granger Cause lnGDP & 453.782 & 0.0371 \\
\hline lnCPI does not Granger Cause lnFDI & 9.88201 & 0.0025 \\
\hline lnDI does not Granger Cause lnCPI & 1.29832 & 0.2588 \\
\hline
\end{tabular}

When the Table-10 is examined, in Balkan Countries -specific, the hypothesis that GDP is not Granger cause of CPI is accepted; in the same analysis, the hypothesis that CPI is not Granger cause of GDP is rejected. According to this result obtained, in Balkan countries, CPI affects GDP but GDP does not affect CPI. Depending on this, for Balkan Countries to increase their economic growth, it emerges that the countries have to increase their transparency degree. Through the same table, while the hypothesis that FDI is not Granger cause of CPI is accepted, the hypothesis that CPI is not Granger cause of FDI is rejected. Depending on this result, transparency structure of Balkan Countries affects foreign direct investments and, for being able to attract more foreign direct investment, it emerges that Balkan countries have to improve their transparency structures

\section{Conclusion}

After disintegration of Union of Soviet Socialist Republic, large changes emerged all over the world and, especially socialist countries called Iron Curtain countries were much more affected from this case. In Balkans region, Yugoslavia, Bulgaria, Romania, and Albania are among these countries specified. These countries, in addition to that the regime changes they experienced, large scaled changes experienced in their borders. After especially disintegration of Yugoslavia, many new countries emerged and this case formed rather large chaotic structures. However, it is unavoidable that every chaotic structure consequently transforms into stable economic structure, and depending on this heavy efforts in this region, a stable economic structure could be provided. Certainly, the region has many problems and, for coming over these problems, transparency comes into face as an important factor. In order to identify transparency problem of regional countries and the effects of this problem on economic growth and utilizing international finance resources, the current study was made. As a result of the study carried out, the identifications given in items below emerged. 
In Balkan countries, positive co-integration relationship between CPI and GDP and the affecting rate of CDI GDP was calculated as 0.34 .

- The direction of causality between CDI and GDP was identified from CDI to GDP and, according to this, the hypothesis that CDI is the cause of GDP was accepted.

- In Balkan Countries, it was identified that there was a positive directional co-integration between CPI and FDI and the affecting rate of CDI the FDI was calculated as 4.60.

- The direction of causality between CDI and FDI was identified from CDI to FDI and, according to this, the hypothesis that CDI is the cause of FDI was accepted.

- Raising CPI values that are at low level (reducing corruption) will make significantly contribution to the economic structures of Balkan countries.

\section{References}

Ackerman, S. R. (1999). Corruption and government, causes, consequences, and reform. Cambridge: Cambridge University Press.

Andving, J., Fjeldstad, O., \& Sissener, T. (2000). Research on corruption: a policy oriented survey. Final Repor. December. Oslo: Commissioned by NORAD.

Gülmez, A. (2015). OECD ülkelerinde ekonomik büyüme ve hava kirliliği ilişkisi: Panel veri analizi. Kastamonu Üniversitesi İktisadi ve İdari Bilimler Fakültesi Dergisi, 9(3), 18-30.

Gillanders, R., \& Neselevska, O. (2018). Public sector corruption and trust in the private sector. Journal of International Development(30), 1288-1317.

Gurgur, T., \& Shah, A. (2014). Localization and corruption: Panacea or pandora's box? Annals of economics and finance, Society for AEF, May, 15(1), 109-136.

Lučić, D., Radišić, M., \& Dušan, D. (2016). Causality between corruption and the level of gdp. Economic Research-Ekonomska Istraživanja, 29 (1), 360-379.

Kao, C., \& Chiang, M.H. (1998). On the estimation and Inference of a cointegrated regression in panel data. Working Paper, Center for Policy Research, Syracuse University.

Koçak, E., \& Nisfet, U. (2018). Demokrasi, ekonomik özgürlükler ve ekonomik büyüme: Kurumların rolü üzerine bir araştırma. Sosyoekonomi, 26(36), 81-102.

Kök, R., \& Şimşek, N., (2006). Endüstri-İçi Dış Ticaret, Patentler ve Uluslar Arası Teknolojik Yayılma. UEK TEK Uluslararası Ekonomi Konferans1, 11-13 Eylül, Ankara.

Kök, Recep, M. Serdar İSPİR \& A. Aydır ARI (2010). Zengin ülkelerden azgelişmiş ülkelere kaynak aktarma mekanizmasının gerekliliği ve evrensel bölüşüm parametresi üzerine bir inceleme. Uluslararası ekonomi konferans1, Türkiye Ekonomi Kurumu, 1-3 Eylül, Girne.

Mani, M., Fredriksson, P., \& Richard, D. (2004). The persistence of corruption and regulatory compliance failures: Theory and evidence. Public Choice. 121(3-4), 363-390.

Mark, N.C., \& Sul, D (2003). Co integration vector estimation by panel dols and long-run money demand. Oxford Bulletin of Economics and Statistics, 65(5), 655-680.

Mustapha, N. (2014). The impact of corruption on GDP per capita. Journal of Eastern European And Central Asian Research, 1(2), 1-5.

Nazlığlu, Ş. (2010). Makro iktisat politikalarının tarım sektörü üzerindeki etkileri: Gelişmiş ve gelişmekte olan ülkeler için bir karşılaştırma. Unpublished Phd Thesis. Institute of social sciences of Erciyes University, Economy. Kayseri. 
Paldam, M. (2001). Corruption and religion adding to the economic model. Kyklos International Review For Social Sciences, 54(2/3), 383-414.

Paldam, M. (2002). The cross-country pattern of corruption: economics, culture and the seesaw dynamics. European Journal of Political Economy, 18(2), 215-240.

Pedroni, P. (2000). Fully modified ols for heterogeneous cointegrated panels. Advances in Econometrics, (15), 93-130.

Pedroni, P. (2001). Purchasing power parity tests in cointegrated panels. Review of Economics and statistics, 83(4), 727-731.

Rose, R., \& Mishler, W. (2010). Experience versus perception of corruption: Russia as a test case. Global Crime, 11(2), 145-163.

Rothstein, B., \& Holmberg, S. (2011). Correlates of corruption. The Quality of Goverment Institute. Gotenburg: University of Gothenburg.

Stapenhurst, R. (2000). The media's role in curbin corruption (No:20433). Washington DC, USA: World Bank Institute (WBI).

Tanzi, V., \& Davoodi, H. (2000). Corruption, growth and public finances. IMF Working Paper, Nowember, IMF.

Thach, N., Duong, M., \& Oanh, T. (2017). Effects of corruption on economic growth - empirical study of asia countries. Imperial Journal of Interdisciplinary Research, 3(7), 791-804.

Uğur, N., \& Dasgupta, M. (2011). Evidence on the economic growth impacts of corruption in lowincome countries and beyond: A systematic review. London: Eppi-Centre. Social Science Research Unit, Institute of Education, University of London.

Ulman, S.R. (2014). Different levels of corruption influence on the main components of the macroeconomic environment. Procedia Economics and Finance 16, 438-447.

Vasileva, V. (2017). The place of balkan countries in world tourism. International Scientific Refereed Online Journal With Impact Factor, (29), 33-43.

Vito , T. (1998). Corruption around the world: Causes, consequences, scope, and cures. (Erişim Tarihi: 01.03.2019, www.Transperency.org./Cpi). 